\title{
Dampak Teknik Sadap Terhadap Penerimaan Petani Karet di Kabupaten Tanjung Jabung Timur
}

\author{
Rizki Gemala Busyra \\ Program Studi Agribisnis Fakultas Pertanian Universitas Batanghari \\ J1. Slamet Riyadi, Broni Jambi. 36122. Telp.+62741-60103 \\ e-mail : rizki.gemala.busyra@unbari.ac.id
}

\begin{abstract}
One of the way to increase rubber productivity and its production, is by focusing to recommended tapping techniques. In East Tanjung Jabung Regency although the recommended rubber tapping technique (i.e. spiral tapping technique) had been socialized, but there were still many rubber farmers who done a non-spiral tapping techniques. This will certainly affect the amount of latex production and the rubber plants life duration. The low amount of rubber production will lead to a low number of sales, so it will have an impact on the low revenue of rubber farmers. The purpose of this study was to find out the impact of the application of spiral tapping techniques on rubber crops toward farmer. The results showed that simultaneously the independent variables had a Significant effect on the Farmer revenues. Partially, rubber production and rubber prices had showed a significant effect on farmer's revenues, while the age of crops and tapping techniques, had no significant effect on the farmer's revenues. Although the variables of tapping techniques did not significantly effect to the farmer revenue but it gave the higher revenue than the other tapping techniques.
\end{abstract}

Keywords : Tapping, Technique, Rubber, Farmer Revenue

\begin{abstract}
Abstrak. Salah satu cara dalam meningkatan produktivitas dan produksi karet, adalah dengan cara memperhatikan teknik penyadapan yang sudah sesuai dengan anjuran. Di Kabupaten Tanjung Jabung Timur walaupun teknik penyadapan karet yang dianjurkan (yaitu teknik sadap spiral) sudah disosialisasikan, namun masih banyak juga petani karet yang melakukan teknik sadap non spiral. Hal ini tentunya akan mempengaruhi pada jumlah produksi lateks dan lamanya umur ekonomi tanaman karet. Jumlah produksi karet yang rendah akan menyebabkan jumlah penjualan yang rendah pula, sehingga akan berdampak pada rendahmya penerimaan petani karet. Tujuan dari penelitian ini adalah untuk mengetahui dampak penggunaan teknik penyadapan secara spiral pada tanaman karet terhadap penerimaan petani. Hasil penelitian menunjukkan secara simultan variabel-variabel bebas memberikan pengaruh secara nyata terhadap penerimaan petani karet. Secara parsial, produksi karet dan harga karet merupakan faktor yang signifikan berpengaruh nyata terhadap penerimaan petani, sedangkan umur tanaman dan teknik penyadapan, tidak berpengaruh secara nyata terhadap penerimaan petani karet di Kabupaten Tanjung Timur. Walaupun variabel teknik sadap tidak berpengaruh secara siginifikan terhadap penerimaan petani karet, namun penerimaan petani karet yang melakukan teknik sadap spiral lebih tinggi dibandingkan dengan petani karet yang tidak menggunakan teknik sadap spiral.
\end{abstract}

Kata Kunci : Teknik Sadap, Karet, Penerimaan Petani

\section{PENDAHULUAN}

Karet merupakan salah satu komoditas perkebunan yang memiliki arti penting bagi perekonomian Indonesia, baik sebagai sumber devisa negara non migas, sumber pendapatan masyarakat, penyedia lapangan kerja bagi sekitar 1.5 juta kepala keluarga, pemasok bahan baku industri, sebagai pelestari sumber daya alam dan lingkungan, dan berperan penting dalam mendorong pertumbuhan sentra-sentra ekonomi baru pada wilayah sentra produksi karet (RG Busyra, 2014).

Propinsi Jambi merupakan salah satu sentra produksi karet di Indonesia. Tanaman karet memegang peranan penting dalam perekonomian wilayah Provinsi Jambi, hal ini dapat dilihat dari peranan tanaman karet dalam menciptakan kesempatan kerja di Provinsi Jambi. Dari data statistik diperoleh informasi bahwa 63,22\% penduduk Provinsi Jambi kegiatan ekonomi dan mata pencahariannya berkaitan dengan komoditas karet. Luas perkebunan karet di Provinsi Jambi 667,114 Ha dan 348,551 Ton (Nofriadi \& BPS,2018).

Kabupaten Tanjung Jabung Timur merupakan salah satu kabupaten penghasil karet di Provinsi Jambi. Walaupun luas lahan karet di Kabupaten Tanjabtim menempati posisi ke 8 namun produktivitasnya tetap berada diatas rata-rata produkivitas karet Provinsi Jambi yaitu sebesar 0,47 Ton/Ha (Dinas Perkebunan Provinsi Jambi, 2018).

Salah satu cara dalam meningkatan produktivitas dan produksi karet, disamping ditentukan oleh keadaan tanah dan pertumbuhan tanaman, penggunaan klon unggul, juga dipengaruhi oleh teknik dan manajemen penyadapan. Penyadapan, yaitu membuka pembuluh lateks pada kulit pohon agar getah mengalir. Teknik penyadapan karet bertujuan untuk meningkatkan produksi lateks dan memperpanjang masa pengaliran lateks tanaman karet (Dewi, 2017).

Teknik sadap yang sering digunakan oleh petani pada perkebunan rakyat adalah teknik sadap berbentuk V (alur sadap V), teknik sadap berbentuk sembarang (alur sadap C) dan teknik sadap spiral (alur sadap S atau berbentuk spiral). Teknik sadap yang dianjurkan adalah teknik sadap spiral, karena teknik ini mempunyai 
keunggulan diantaranya, (1) Memperpanjang alur sadap, (2) Memperoleh aliran lateks yang baik, dan (3) Menghindari adanya jalur kulit yang tidak tersadap.

Di Kabupaten Tanjung Jabung Timur walaupun teknik penyadapan karet yang dianjurkan (yaitu teknik sadap spiral) sudah disosialisasikan, namun masih banyak juga petani karet yang melakukan teknik sadap non spiral. Hal ini tentunya akan mempengaruhi pada jumlah produksi lateks dan lamanya umur ekonomi tanaman karet. Jumlah produksi karet yang rendah akan menyebabkan jumlah penjualan yang rendah pula, sehingga akan berdampak pada rendahmya penerimaan petani karet. Melihat fenomena diatas menyebabkan peneliti tertarik untuk melakukan penelitian mengenai "Dampak Teknik Sadap Spiral Terhadap Penerimaan Petani Karet di Kabupaten Tanjung Jabung Timur".

\section{METODE PENELITIAN}

Penelitian dan pengambilan data dilapangan dilaksanakan pada bulan Maret sampai Juli 2021, di Kabupaten Tanjung Jabung Timur Provinsi Jambi.

Jenis data menurut skala pengukuran yang digunakan dalam penelitian ini adalah data rasio. Jenis data menurut waktunya adalah data cross section. Sumber data yang digunakan adalah data primer dan data sekunder. Data Primer berupa data yang diambil langsung dari petani yang terpilih sebagai sampel, pengambilan data dilakukan dengan wawancara langsung pada responden dengan menggunakan daftar pertanyaan yang terpola dan terstruktur sesuai dengan kebutuhan. Data Sekunder merupakan data tambahan yang diperoleh dari Dinas Pertanian Provinsi Jambi, Dinas Pertanian Kabupaten Tanjung Jabung Timur, Dinas Perkebunan, Badan Pusat Statistik (BPS) Jambi, Badan Pengkajian Teknologi Pertanian (BPTP) Jambi, Dinas Perindustrian dan Perdagangan Provinsi Jambi, dan dari berbagai informasi-informasi lain seperti jurnal-jurnal pertanian, ekonomi dan hasil penelitian terdahulu serta pada beberapa situs di internet. Penelitian dilakukan dengan metode survey.

Pengambilan lokasi penelitian dilakukan secara purposive, yaitu dengan mengambil Kabupaten Tanjung Jabung Timur sebagai tempat penelitian, dikarenakan wilayah ini sebagai salah satu penghasil karet di Provinsi Jambi (Dinas Perkebunan Provinsi Jambi, 2018). Populasi petani yang mengusahakan tanaman Karet di Kabupaten Tanjung Jabung Timur berjumlah 5283 orang. Besarnya ukuran sampel yang diambil menggunakan rumus slovin, dengan derajat kesalahan $15 \%$. Rumus Slovin dapat dilihat sebagai berikut :

$$
\mathrm{n}=\frac{\mathrm{N}}{1+\mathrm{N}(\mathrm{e})^{2}}=\frac{5283}{1+5283(0,15)^{2}}=\frac{5283}{119,86}=44
$$

Keterangan:

$\mathrm{n} \quad=$ Jumlah Sampel

$\mathrm{N} \quad=$ Jumlah Populasi

e $\quad=$ Derajat Kesalahan yang digunakan sebesar $15 \%$

Jadi besarnya sampel yang diambil sebanyak 44 orang. Hal ini sesuai dengan pernyataan (Winarno, 2004), untuk jumlah manusia hendaknya diambil diatas 30 sebagai sampel. Dengan teknik pengambilan sampel secara acak sederhana (simple random sampling). Yang merupakan salah satu teknik pengambilan sampel yang dilakukan dengan cara acak sehingga setiap petani memiliki peluang yang sama untuk dipilih sebagai sampel.

Penerimaan petani karet merupakan perkalian antara harga produk dengan jumlah produk yang dihasilkan. Besarnya nilai penerimaan dapat dihitung dengan menggunakan rumus (Hernanto, F, 1996), sebagai berikut :

TR $=$ Hy. $\mathbf{Y}$

Keterangan :

TR $=$ Total Penerimaan Petani Karet $(\mathrm{kg} / \mathrm{ha} / \mathrm{sdp})$

Hy = Harga Bokar Karet $(\mathrm{Rp} / \mathrm{Kg})$

$\mathrm{Y}=$ Jumlah Produksi Bokar $(\mathrm{Kg} / \mathrm{ha} / \mathrm{sdp})$

Model merupakan suatu penjelas dari fenomena aktual sebagai suatu sistem atau proses (Koutsoyiannis, 1977). Model ekonometrika adalah suatu pola khusus dari model aljabar, yakni suatu unsur yang bersifat stochastic yang mencakup satu atau lebih peubah pengganggu (Intriligator, 1978).

Model ekonometrika merupakan gambaran dari hubungan masing-masing variabel penjelas (explanatory variables) terhadap peubah endogen (dependent variables) khususnya yang menyangkut tanda dan besaran (magnitude and sign) dari penduga parameter sesuai dengan harapan teoritis secara apriori. Model yang baik haruslah memenuhi kriteria teori ekonomi (theoritically meaningful), kriteria statistika yang dilihat dari suatu derajat ketepatan (goodness of fit) yang dikenal dengan koefisien determinasi $\left(\mathrm{R}^{2}\right)$ serta nyata secara statistik (statistically significant) sedangkan kriteria ekonometrika menetapkan apakah suatu taksiran memiliki sifat-sifat yang dibutuhkan seperti unbiasedness, consistency, sufficiency, efficiency. Statistik $\mathrm{D}_{\mathrm{w}}$ adalah salah satu kriteria ekonometrika yang digunakan untuk menguji taksiran, yaitu menguji validitas dari asumsi autocorrelation (Koutsoyiannis, 1977). 
Model yang dirumuskan dalam penelitian ini adalah sangat terkait dengan tujuan penelitian yaitu bagaimana dampak teknik sadap spiral terhadap penerimaan petani karet. Persamaan yang disusun adalah persamaan penerimaan. Penerimaan petani karet di Kabupaten Tanjung Jabung Timur diduga dipengaruhi oleh produksi karet, harga karet, umur tanaman, dan teknik penyadapan.

$\mathrm{R}=\mathrm{a}_{0}+\mathrm{a}_{1} \mathrm{QK}+\mathrm{a}_{2} \mathrm{HK}+\mathrm{a}_{3} \mathrm{UT}+\mathrm{a}_{4} \mathrm{TS}+\mathrm{U}$

dimana:

$\mathrm{R}=$ Penerimaan Petani Karet $(\mathrm{Rp} / \mathrm{Ha} / \mathrm{Sadap})$

$\mathrm{QK} \quad=$ Produksi Karet $(\mathrm{Kg} / \mathrm{Ha})$

HK = Harga Karet $(\mathrm{Rp} / \mathrm{Kg})$

UT = Umur Tanaman (Tahun)

TS = Teknik Sadap:

$\mathrm{D} \quad=1$ untuk penyadapan teknik spiral;

$\mathrm{D} \quad=0$ untuk penyadapan non spiral)

$\mathrm{U} \quad=$ Faktor kesalahan / Error

$\mathrm{a}_{1}, \mathrm{a}_{2}, \mathrm{a}_{3}, \mathrm{a}_{4}=$ Parameter yang digunakan

Tanda parameter dugaan yang diharapkan:

$\mathrm{a}_{1}, \mathrm{a}_{2}, \mathrm{a}_{3} \geq 0 ; \quad \mathrm{a}_{3} \leq 0 ; \quad 0 \leq \mathrm{a}_{4} \leq 1$

Untuk mengetahui dan menguji apakah variabel penjelas secara bersama-sama berpengaruh nyata atau tidak terhadap variabel endogen, maka pada setiap persamaan digunakan uji statistik $\mathrm{F}$, dan untuk menguji apakah masing-masing variabel penjelas berpengaruh nyata atau tidak terhadap variabel endogen, maka pada setiap persamaan digunakan uji statistik t.

Selain itu dilakukan juga uji asumsi klasik yang terdiri dari beberapa uji berikut ini :

\section{a). Uji Multikolinearitas}

Multikolinearitas menandakan bahwa terdapat hubungan linear (korelasi) yang sempurna atau pasti, diantara beberapa atau semua variabel yang menjelaskan dari model regresi (Gujarati, 2003). Model regresi yang baik seharusnya tidak terjadi hubungan linear diantara variabel independen. Menurut Ghozali (2008), bahwa untuk mendeteksi ada tidaknya multikolinearitas didalam model regresi adalah sebagai berikut :

- Menganalisis matrik korelasi variabel-variabel independen. Jika antar variabel independen ada korelasi yang cukup tinggi (umumnya di atas 0,90), maka hal ini merupakan indikasi adanya multikolinearitas.

- Multikolinearitas dapat juga dilihat dari (1) nilai tolerance dan lawannya (2) Variance Inflation Factor (VIF). Kedua ukuran ini menunjukkan setiap variabel independen manakah yang dijelaskan oleh variabel independen lainnya. Dalam pengertian sederhana setiap variabel independen menjadi variabel dependen dan diregresikan terhadap variabel independen lainnya. Tolerance mengukur variabilitas variabel independen lainnya. Jadi nilai tolerance yang rendah sama dengan nilai VIF yang tinggi (karena VIF=1/nilai tolerance). Nilai cut off yang umum dipakai untuk menunjukkan adanya multikolinearitas adalah nilai tolerance $>0,10$ atau sama dengan nilai $\mathrm{VIF}<10$.

\section{b). Uji Heteroskedastisitas}

Uji heteroskedastisitas digunakan untuk menguji apakah dalam suatu model regresi terjadi ketidaksamaan variance dan residual dari satu pengamatan ke pengamatan yang lain. Jika variance dari residual satu pengamatan ke pengamatan lain tetap, maka disebut homoskedastisitas dan jika berbeda maka disebut heteroskedastisitas (Ghozali, 2008). Adapun cara untuk mendeteksi ada atau tidaknya heteroskedastisitas menurut Ghozali (2008), yaitu dengan melihat grafik scatterplot antara nilai prediksi variabel dependen yaitu ZPRED dengan residualnya SRESID. Deteksi ada tidaknya heteroskedastisitas dapat dilakukan dengan melihat ada tidaknya pola tertentu pada grafik scatterplot dimana sumbu Y adalah Y yang telah diprediksi, dan sumbu X adalah residual (Y prediksi - Y sesungguhnya). Adapun dasar pengambilan keputusan dilakukan dengan dasar analisis sebagai berikut :

- Jika ada pola tertentu, seperti titik-titik yang ada membentuk pola yang teratur (bergelombang, melebar, menyempit), mengindikasikan telah terjadi heteroskedastisitas.

- Jika tidak ada pola yang jelas, serta titik-titik menyebar diatas dan dibawah angka 0 pada sumbu Y, maka tidak terjadi heteroskedastisitas.

\section{c). Uji Asumsi Normalitas}

Uji asumsi normalitas digunakan untuk menguji apakah dalam suatu model regresi, variabel dependen atau keduanya mempunyai distribusi normal atau mendekati normal (Santoso, 2000). Apabila asumsi ini tidak terpenuhi, baik 
uji $\mathrm{F}$ ataupun uji-t, dan nilai estimasi nilai variabel dependen menjadi tidak valid (Utomo, 2007). Untuk mendekati normalitas pada model regresi yaitu dengan melihat penyebaran data (titik) pada sumbu diagonal dari grafik normal. Adapun dasar pengambilan keputusannya berdasarkan kriteria uji :

- Jika data menyebar di sekitar garis diagonal dan mengikuti arah garis diagonal, maka model regresi memenuhi asumsi normalitas.

- Jika data menyebar jauh dari garis diagonal dan tidak mengikuti arah garis diagonal, maka model regresi tidak memenuhi asumsi normalitas.

\section{d). Uji Autokorelasi}

Uji autokorelasi adalah salah satu bagian dari uji asumsi klasik dimana suatu persamaan regresi dikatakan telah memenuhi asumsi tidak terjadi autokorelasi dengan menggunakan uji Durbin Watson. Menurut Santoso (2000) bahwa tujuan uji autokorelasi adalah untuk mengetahui apakah dalam suatu model regersi linear ada korelasi antara kesalahan pengganggu dengan kesalahan sebelumnya. Apabila hal ini terjadi maka terdapat masakah autokorelasi. Adapun kritik pengujiannya adalah jika $d u<d<4-d u$ maka Ho ditolak yang berarti tidak ada autokorelasi baik positif maupun negatif. Untuk mengetahui ketepatan model regresi sampel dalam menaksir nilai aktualnya dapat diukur dari goodness of fit- nya. Goodness of fit dalam model regresi dapat diukur dari nilai koefisien determinasi, nilai statistik F, dan uji statistik t.

\section{HASIL PENELITIAN}

\section{A. Gambaran Variabel Bebas Yang Mempengaruhi Penerimaan Petani Karet}

\section{Produksi Karet}

Produksi karet merupakan kegiatan dalam menciptakan dan menambah kegunaan (utility) barang yang berupa lateks/bokar. Jumlah produksi karet petani sampel berkisar antara $9-47 \mathrm{~kg} / \mathrm{Sadap}$. Hal ini dapat dilihat pada Tabel 1. berikut ini.

Tabel 1. Distribusi Frekuensi Petani Berdasarkan Produksi Karet Di Daerah Penelitian.

\begin{tabular}{cccc}
\hline No. & $\begin{array}{c}\text { Distribusi Produksi Karet } \\
\text { Kg/Ha/Sadap }\end{array}$ & $\begin{array}{c}\text { Frekuensi } \\
\text { (RTP) }\end{array}$ & Persentase $(\%)$ \\
\hline 1 & $9-14,43$ & 7 & 15 \\
2 & $14,44-19,87$ & 6 & 13 \\
3 & $19,88-25,31$ & 8 & 17 \\
4 & $25,32-30,75$ & 10 & 21 \\
5 & $30,75-36,18$ & 5 & 11 \\
6 & $36,19-41,62$ & 7 & 15 \\
7 & $4,63-47,06$ & 4 & 9 \\
\hline & Jumlah & 47 & 100 \\
\hline
\end{tabular}

Sumber : Olahan Data Primer Tahun 2021

Tabel 1 menunjukan bahwa frekuensi produksi terbanyak ada pada distribusi 25,32-30,75 Kg/Ha/Sadap yaitu sebanyak 10 RTP (21\%), dan frekuensi produksi terkecil berada pada 4,63-47,06 Kg/Ha/Sadap yaitu sebanyak 4 RTP. Dengan rata-rata produksi karet petani sampel persadapan adalah $26.51 \mathrm{Kg} / \mathrm{Sadap}$.

\section{Harga Karet}

Harga karet adalah ukuran nilai dari barang-barang dan jasa. Harga karet komoditi perkebunan merupakan salah satu faktor yang menentukan dalam kelanjutan akan suatu usahatani, karena tingkat harga karet pada saat panen dapat berubah-ubah dan sangat menentukan tingkat penerimaan petani karet. Harga karet-karet petani berkisar antara 6.000-6.800. Untuk perbedaan tingkat harga karet dapat dilihat pada Tabel 2 Berikut.

Tabel 2. Distribusi dan Frekuensi Petani Berdasarkan Harga Karet di Daerah Penelitian.

\begin{tabular}{cccc}
\hline No. & $\begin{array}{c}\text { Distribusi Harga Karet } \\
(\mathrm{Rp} / \mathrm{Kg})\end{array}$ & $\begin{array}{c}\text { Frekuensi } \\
(\mathrm{RTP})\end{array}$ & Persentase $(\%)$ \\
\hline 1 & $6.000-6.114$ & 9 & 19 \\
2 & $6.115-6.239$ & 4 & 9 \\
3 & $6.230-6.344$ & 6 & 13 \\
4 & $6.345-6.460$ & 11 & 23 \\
5 & $6.460-6.575$ & 8 & 17 \\
6 & $6.575-6.689$ & 2 & 4 \\
7 & $6.690-6.804$ & 7 & 15 \\
\hline
\end{tabular}

Sumber : Olahan Data primer Tahun 2021. 
Tabel 2 menunjukan bahwa frekukensi harga karet terbanyak ada pada distribusi $6.345-6.460 \mathrm{Rp} / \mathrm{Kg}$ yaitu sebanyak 11 RTP (23\%), dan yang terkecil berada pada distribusi 6.575-6689 Rp/Kg. Dengan rata-rata harga karet petani adalah $6.373,33 \mathrm{Rp} / \mathrm{Kg}$.

\section{Umur Tanaman}

Dari hasil penelitian dilapangan diketahui umur tanaman karet berkisar antara 7 sampai dengan 40 tahun. Hal ini dapat dilihat pada Tabel 3.

Tabel 3. Distribusi Frekuensi Petani Berdasarkan Umur Tanaman Karet di Daerah Penelitian

\begin{tabular}{cccc}
\hline No. & Umur Tanaman (Tahun) & Frekuensi (RTP & Persentase $\%)$ \\
\hline 1 & $7-11$ & 13 & 28 \\
2 & $12-16$ & 10 & 21 \\
3 & $17-21$ & 12 & 11 \\
4 & $22-26$ & 5 & 2 \\
5 & $27-31$ & 1 & 6 \\
6 & $32-36$ & 3 & 6 \\
7 & $37-41$ & 3 & 100 \\
\hline
\end{tabular}

Sumber : Olahan Data Primer Tahun 2021

Dari Tabel 3 terlihat bahwa frekuensi petani terbanyak ada pada distribusi umur tanaman karet 7 - 11 Tahun yaitu sebanyak 13 RTP (28\%) dan frekuensi terendah ada pada distribusi umur 27 - 31 tahun, yaitu sebanyak 1 RTP (2\%). Dengan rata-rata umur tanaman karet 18,37 tahun. Umur tanaman karet petani sebagian besar sudah mendekati periode umur produksi konstan, yaitu pada kondisi optimum, karet mulai bisa disadap pada umur 6 tahun setelah itu tanaman masuk pada periode produksi konstan hingga 25-30 tahun. Semakin bertambahnya umur tanaman karet maka kemampuan karet untuk berproduksi juga akan semakin menurun, maka produktifitasnya juga akan menurun.

\section{Teknik Penyadapan}

Berdasarkan hasil penelitian dapat diketahui teknik penyadapan karet didaerah penelitian menerapkan dua teknik penyadapan yaitu spiral dan bukan spiral. Distribusi frekuensi petani berdasarkan penyadapan tanaman karet dapat dilihat pada Tabel 4.

Tabel 4. Distribusi Frekuensi Petani Berdasarkan Teknik Penyadapan Tanaman Karet Di Daerah Penelitian

\begin{tabular}{llcc}
\hline No & Teknik Penyadapan & Jumlah (RTP) & Persentase (\%) \\
\hline 1 & Teknik Spiral & 20 & 43 \\
2 & Teknik Bukan Spiral & 27 & 57 \\
\hline & Jumlah & 47 & 100 \\
\hline
\end{tabular}

Sumber : Olahan Data Primer Tahun 2021

Berdasarkan Tabel 4 diatas, petani di daerah penelitian mayoritas menerapkan teknik penyadapan bukan spiral yaitu sebanyak 27 RTP (57\%).

\section{B. Gambaran Penerimaan Petani Karet}

Penerimaan usahatani karet adalah nilai uang yang diterima oleh penjualan yang merupakan perkalian antara jumlah produksi dengan harga karet. Distribusi penerimaan usahatani karet di daerah penelitian dapat dilihat Pada Tabel 5 berikut.

Tabel 5. Distribusi Frekuensi Petani Berdasarkan Penerimaan Usahatani Karet

\begin{tabular}{cccc}
\hline No & $\begin{array}{c}\text { Distribusi Penerimaan Petani } \\
(\text { Rp/Ha/Sadap) }\end{array}$ & $\begin{array}{c}\text { Frekuensi } \\
(\text { RTP })\end{array}$ & $\begin{array}{c}\text { Persentase } \\
(\%)\end{array}$ \\
\hline 1 & $28.350-43.728$ & 5 & 11 \\
2 & $43.729-59.107$ & 12 & 26 \\
3 & $59.108-74.486$ & 7 & 15 \\
4 & $74.487-89.865$ & 10 & 21 \\
5 & $89.866-105.244$ & 6 & 13 \\
6 & $105.245-120.623$ & 2 & 4 \\
7 & $120.624-136.002$ & 5 & 11 \\
\hline & Jumlah & 47 & 100 \\
\hline
\end{tabular}

Sumber : Olahan Data Primer Tahun 2021 
Berdasarkan Tabel 5 di atas, persentase untuk tingkat penerimaan petani karet yang terbesar pada kelas 2 yaitu dengan kisaran Rp.43.729-59.107/Ha/Sadap sebanyak 12 RTP (26\%). Sedangkan untuk persentase terkecil pada kelas 6 yaitu dengan kisaran Rp.105.246-120.623/Ha/Sadap sebanyak 2 RTP (4\%).

\section{Dampak Teknik Sadap Spiral Terhadap Penerimaan Petani Karet Di Kabupaten Tanjung Jabung Timur}

Dalam penelitian ini diduga bahwa teknik sadap spiral merupakan salah satu faktor yang mempengaruhi penerimaan petani karet di Kabupaten Tanjung Jabung Timur. Faktor lainnya yang diduga mempengaruhi penerimaan petani karet adalah produksi karet, harga karet, dan umur tanaman. Untuk melihat pengaruh faktorfaktor tersebut digunakan model ekonometrika dengan persamaan regresi linear berganda dengan bantuan alat analisis program SPSS. Sebelum dilakukan estimasi model regresi berganda tersebut, data yang digunakan harus dipastikan terbebas dari penyimpangan asumsi klasik diantaranya uji multikolinearitas, heteroskesdasitas, normalitas dan autokorelasi. Hasil uji asumsi klasik dalam penelitian ini adalah sebagai berikut :

\section{Hasil Uji Asumsi Klasik}

\section{a). Uji Multikolinearitas}

Uji multikolinearitas adalah digunakan untuk mengetahui apakah terjadi hubungan antar variabel independen dengan variabel independen lainnya. Apabila hal ini terjadi, maka terjadi masalah multikolinearitas sebab model regresi yang baik seharusnya tidak terjadi korelasi diantara variabel independennya. Berdasarkan hasil analisis data uji multikolinearitas dengan menggunakan nilai VIF dan nilai tolerance menunjukan tidak terjadi multikolinearitas pada model regresi, untuk lebih jelas dapat dilihat pada Tabel 6.

Tabel 6. Hasil Uji Multikolinearitas dengan menggunakan Nilai VIF

\begin{tabular}{|c|c|c|c|}
\hline Variabel & Tolerance & Nilai VIF & Keterangan \\
\hline Produksi Karet $\left(\mathrm{X}_{1}\right)$ & 0,742 & 1.348 & Tidak terjadi Multikolinearitas \\
\hline Harga Karet $\quad\left(X_{2}\right)$ & 0,509 & 1.965 & Tidak terjadi Multikolinearitas \\
\hline Umur Tanaman $\left(\mathrm{X}_{3}\right)$ & 0,503 & 1.989 & Tidak terjadi Multikolinearitas \\
\hline Teknik Sadap $\left(\mathrm{D}_{4}\right)$ & 0,788 & 1.269 & Tidak terjadi Multikolinearitas \\
\hline
\end{tabular}

Sumber : Data Primer yang Diolah, Tahun 2021

\section{b). Uji Heteroskedastisitas}

Uji heteroskedastisitas digunakan untuk menguji apakah dalam suatu model regresi terjadi ketidaksamaan variance dan residual dari satu pengamatan ke pengamatan yang lain. Jika variance dari residual satu pengamatan ke pengamatan lain tetap, maka disebut homoskedastisitas, namun apabila berbeda maka terjadi heteroskedastisitas.

Berdasarkan keterangan pada Gambar 1, dapat diketahui bahwa tidak terjadi heteroskedastisitas. Hal ini disebabkan karena tidak ada pola yang jelas serta titik-titik menyebar di atas dan di bawah angka 0 pada sumbu Y, sehingga dapat dikatakan uji heteroskedastisitas terpenuhi.

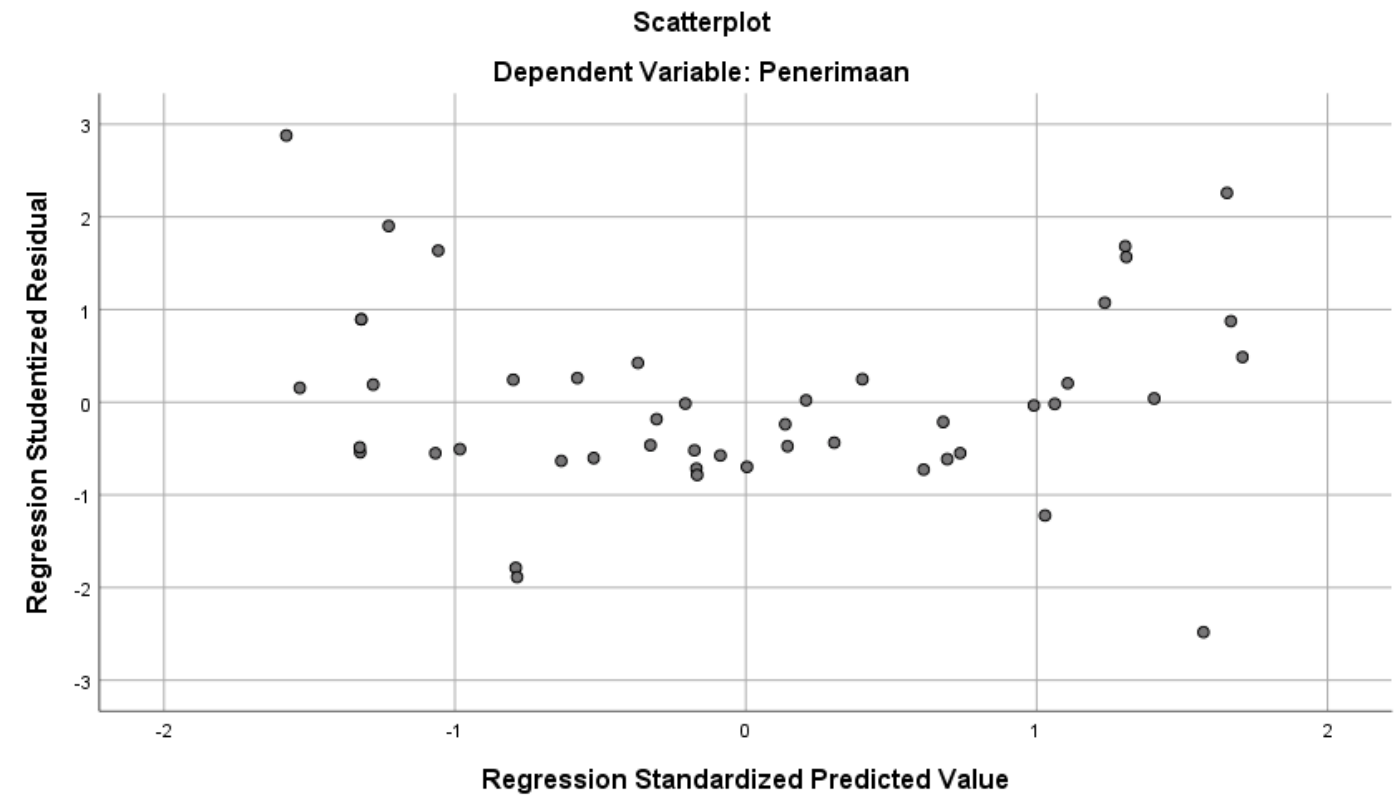

Gambar 1. Grafik Scatterplot Hasil Uji Heteroskedastisitas 


\section{c). Uji Normalitas}

Uji asumsi normalitas digunakan untuk menguji apakah dalam suatu model regresi, varibel dependen atau keduanya mempunyai distribusi normal atau mendekati normal (Santoso, 2000). Berdasarkan penjelasan tersebut bahwa Apabila asumsi normalitas tidak terpenuhi maka baik uji $\mathrm{F}$ ataupun uji-t, dan nilai estimasi nilai variabel dependen menjadi tidak valid. Berdasarkan keterangan Gambar 2, bahwa terlihat titik-titik yang menyebar disekitar garis diagonal serta penyebarannya mengikuti garis tersebut. Dari hasil tersebut dapat disimpulkan bahwa model regresi yang digunakan telah memenuhi asumsi normalitas.

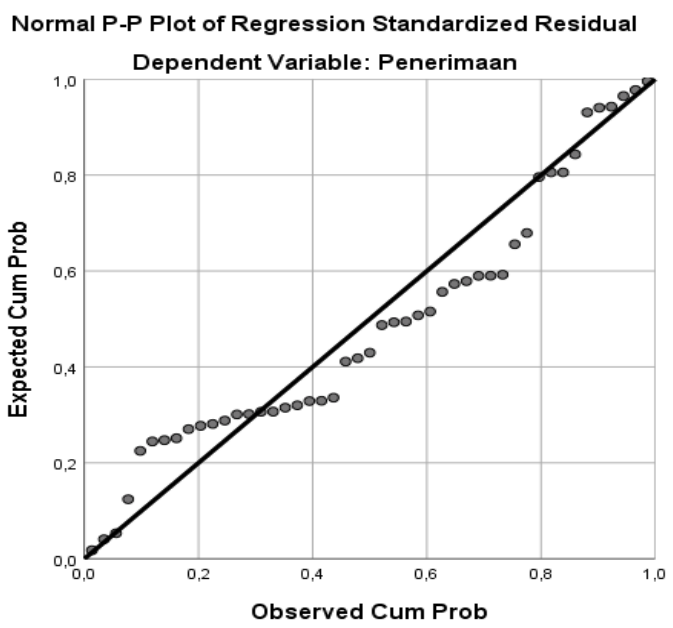

Gambar 2. Gambar Grafik Normal P-Plot

\section{d). Uji Autokorelasi}

Menurut Santoso (2000) bahwa tujuan uji autokorelasi adalah untuk mengetahui apakah dalam suatu model regresi linear ada korelasi antara kesalahan pengganggu dengan kesalahan sebelumnya. Hasil pengujian terhadap model regresi yang dilakukan tidak terdapat autokorelasi, karena nilai DW sebesar 1,844 lebih besar dari batas atas (du) 1,72 dan kurang dari 2 .

\section{A. Pengujian Hipotesis}

Hasil uji asumsi klasik regresi linear berganda untuk mengetahui pengaruh variabel bebas (independen) yaitu produksi karet, harga karet, umur tanaman dan teknik penyadapan terhadap variabel terikat (dependen) atau penerimaan petani karet, dapat dilihat pada Tabel 7.

Tabel 7. Hasil Analisis Regresi Linear Berganda

\begin{tabular}{|c|c|c|c|c|c|}
\hline No. & Variabel & Koefesien Regresi & Thitung & Sig & Ket \\
\hline \multirow[t]{9}{*}{1} & (Constant) & $-203584,555$ & $-14,148$ & ,000 & $\sqrt{ }$ \\
\hline & (X1)Produksi Karet & 6383,650 & 155,156 & ,000 & $\sqrt{ }$ \\
\hline & (X2)Harga Karet & 32,231 & 13,672 & 000 & $\sqrt{ }$ \\
\hline & (X3)Umur Tanaman & $-87,388$ & $-1,490$ & ,144 & $\mathrm{X}$ \\
\hline & (D4)Teknik Penyadapan & 508,235 & ,561 & ,578 & $\mathrm{X}$ \\
\hline & Adjusted R Square & $=0,999$ & Sig F & $=0,000$ & \\
\hline & $F_{\text {hitung }}$ & $=8579,760$ & & & \\
\hline & $F_{\text {tabel }}(4 ; 42)$ & $=2,59$ & & & \\
\hline & $\mathrm{t}_{\text {tabel }}(0,025 ; 47)$ & $=2,01$ & & & \\
\hline
\end{tabular}

Sumber : Data Primer yang Diolah, Tahun 2021

Berdasarkan hasil analisis regresi pada Tabel $7 \mathrm{di}$ atas, diperoleh persamaan regresi: $\mathrm{Y}=-203584,555+6383,650 \mathrm{X} 1+32,231 \mathrm{X} 2-87,388 \mathrm{X} 3+508,235 \mathrm{D} 4+\mathrm{e}$

\section{a). Analisis Uji Keragaman (Uji F)}

Uji statistik yang digunakan untuk menguji besarnya pengaruh seluruh variabel independen digunakan Uji-F, untuk menentukan F table tingkat signifikan yang digunakan sebesar 0,05. Berdasarkan data analisis SPSS diperoleh nilai Fhitung $=8579,760$ lebih besar dari Ftabel sebesar 2,59. Hal yang sama bisa juga dilihat dari nilai signifikansi $\mathrm{F}(0,00)$ yang lebih kecil dari 5\%. Nilai ini menunjukan secara simultan variabel-variabel bebas memberikan pengaruh secara nyata terhadap penerimaan petani karet atau dengan kata lain variabel independen (produksi karet, harga karet, umur tanaman, dan teknik penyadapan) secara bersama-sama berpengaruh nyata terhadap variabel dependen (Penerimaan Petani Karet). 
Hal ini memperkuat bahwa hipotesis penelitian yang menyatakan bahwa faktor produksi karet, harga karet, umur tanaman, dan teknik penyadapan secara bersama-sama berpengaruh terhadap penerimaan petani karet di Kabupaten Tanjung Jabung Timur, dapat diterima.

\section{b). Analisis Uji Koefisien Determinasi $\left(\mathbf{R}^{2}\right)$}

Dari hasil analisis regresi linier berganda diperoleh nilai Adjusted R Square sebesar 0,999 ini menunjukan penerimaan petani karet dapat dijelaskan 99,9\% oleh variabel yang ada di dalam model (Produksi Karet, Harga Karet, Umur Tanaman, dan Teknik Penyadapan) dan sisanya sebesar $0,1 \%$ dijelaskan oleh faktor lain yang tidak termasuk dalam perhitungan atau model. Berarti model yang digunakan untuk analisis ini baik untuk mengestimasi variabel variabel yang diikut sertakan dalam model berdasarkan data yang ada. $\mathrm{R}^{2}$ ini berfungsi untuk mengukur ketepatan yang baik dari persamaan analisis regresi dan jika ada observasi tepat pada garis estimasi maka data hasil sampel hampir mendekati keadaan yang sebenarnya.

\section{c). Analisis Koefisien Regresi (Uji t)}

Dalam persamaan regresi suatu penelitian, nilai koefisien pada masing-masing variabel independen (produksi karet, harga karet, umur tanaman dan teknik penyadapan) harus melalui pengujian secara satu persatu, hal ini bertujuan untuk mengetahui variabel independen yang mana yang memiliki pengaruh nyata terhadap variabel dependen (penerimaan petani karet). Adapun hasil dan pembahasan uji signifikansi akan dijelaskan sebagai berikut :

\section{Produksi Karet (X1)}

Nilai thitung pada variabel produksi karet 155,156 > nilai tabel sebesar 2,01 maka secara statistik produksi karet berpengaruh terhadap penerimaan petani karet. Disisi lain juga bisa dilihat dari uji parsial dimana sig $\mathrm{t}=0,000$ yang lebih kecil dari $\alpha=5 \%$, yang artinya produksi karet berpengaruh nyata terhadap penerimaan petani

Semakin tinggi produksi karet maka penerimaan petani akan semakin meningkat. Jika dihubungkan dengan nilai koefisien regresi (b1) yaitu sebesar 6383,650 ini berarti jika penambahan produksi karet sebesar $1 \mathrm{Kg} / \mathrm{sadap}$ akan terjadi kenaikan penerimaan sebesar Rp. 6.383,650,-.Ha/sadap.

\section{Harga Karet (X2)}

Berdasarkan Uji Parsial yang dilakukan terhadap variabel harga karet (X2), ternyata variabel ini berpengaruh signifikan dilihat dari Sig $t=0,000$ yang lebih kecil dari 0,05 (5\%), atau bisa dilihat dari t hitung 13,672 yang lebih besar jika dibandingkan dengan $\mathrm{t}$ tabel 2,01.

Semakin tinggi harga karet maka penerimaan petani juga akan semakin tinggi, hal ini dikarenakan penerimaan didapatkan dari harga dikali dengan produksi. Jika dihubungkan dengan persamaan dengan nilai koefisien regresi $\left(b_{2}\right)$ yaitu sebesar 32,231 ini berarti jika terjadi kenaikan harga karet sebesar Rp. 1/Kg maka akan terjadi kenaikan penerimaan sebesar Rp. 32,231,-.Ha/sadap.

\section{Umur Tanaman (X3)}

Berdasarkan Uji Parsial yang dilakukan terhadap variabel Umur Tanaman (X3), ternyata variabel ini tidak berpengaruh signifikan dilihat dari Sig $\mathrm{t}=0,144$ yang lebih besar dari $0,05(5 \%)$, demikian pula halnya bisa dilihat dari t hitung -1,490 yang lebih kecil jika dibandingkan dengan t tabel 2,01.

Umur tanaman dihubungkan dengan produksi karet, semakin tua umur tanaman karet maka produksinya akan menurun. Pada saat produksi petani menurun maka ini akan menurunkan penerimaan petani.

\section{Teknik Penyadapan (D4)}

Berdasarkan Uji Parsial yang dilakukan terhadap variabel Teknik Penyadapan (D4), ternyata variabel ini berpengaruh tidak signifikan dilihat dari Sig $\mathrm{t}=0,578$ yang lebih besar dari 0,05 (5\%), disamping itu juga dapat dilihat dari t hitung 0,561 yang lebih kecil jika dibandingkan dengan t tabel 2,01. Dengan demikian hipotesis yang menyatakan bahwa Teknik Penyadapan berpengaruh terhadap penerimaan petani karet tidak dapat diterima. Dari koefisien $\left(b_{4}\right)$ petani yang menyadap dengan kategori spiral penerimaanya lebih tinggi yaitu sebesar Rp. $508,235 / \mathrm{Ha} / \mathrm{Sdp}$ bila dibandingkan dengan penerimaan petani yang tidak menerapkan penyadapan kategori spiral.

\section{KESIMPULAN}

Berdasarkan hasil penelitian yang telah dikemukakan di atas, maka dapat ditarik beberapa kesimpulan sebagai berikut:

1. Dari hasil penelitian diperoleh Fhitung $=8579,760$ lebih besar dari Ftabel sebesar 2,59 artinya menunjukan secara simultan variabel-variabel bebas memberikan pengaruh secara nyata terhadap penerimaan petani karet. Secara parsial, produksi karet dan harga merupakan faktor yang signifikan berpengaruh nyata terhadap penerimaan petani, sedangkan umur tanaman dan teknik penyadapan, tidak berpengaruh secara nyata terhadap penerimaan petani karet di Kabupaten Tanjung Timur. 
2. Walaupun variabel teknik sadap tidak berpengaruh secara siginifikan terhadap penerimaan petani karet, namun penerimaan petani karet yang melakukan teknik sadap spiral lebih tinggi dibandingkan dengan petani karet yang tidak menggunakan teknik sadap spiral.

\section{DAFTAR PUSTAKA}

Anwar, C. 2006. Manajemen dan Teknologi Budidaya Karet. TeknoEkonomi Agribisnis Karet. Indonesia Konsultan. Jakarta.

Badan Pusat Statistik Provinsi Jambi. 2020. Jambi Dalam Angka. Badan Pusat Statistik Provinsi Jambi. Jambi.

Budiman, dan Haryanto. 2012. Budidaya Karet Unggul. Pustaka Baru Press. Yogyakarta.

Busyra, R.G. 2014. Dampak Perluasan Areal Pada Komoditas Karet Terhadap Perekonomia Provinsi Jambi. Journal of Agriculture, Resource and Environmental Economics 1 (2), 12-25.

Busyra, R.G \& Pariyanto. 2018. Faktor-Faktor Yang Mempengaruhi Penerimaan Petani Karet Di Desa Baru Kecamatan Mestong Kabupaten Muaro Jambi. Jurnal Media Agribisnis (MeA) Vol.3 No.1 : 1-11.

Cahyono, B. 2010. Cara Sukses Berkebun Karet. Cetakan Pertama.

Dewi Nur Rokhmah. 2017. Peningkatan Hasil Sadap Karet Menggunakan Etephone. www.balittri.pertanian.go.id. Jawa Barat. Diunduh tanggal 15 Maret 2021.

Ghozali, Imam. 2014. Structural Equation Modelling Metode Alternatif dengan Partial Least Squares (PLS) Edisi 4. Badan Penerbit Universitas Diponegoro. Semarang.

Gujarati, D. 2003. Ekonometrika Dasar. Terjemahan. Erlangga. Jakarta.

Harjadi S.S. 1996. Pengantar Agronomi. PT. Gramedia Pustaka Utama. Jakarta.

Hasan, M. Iqbal. 2008. Pokok-pokok Materi Statistik (Statistik Deskriptif) Bumi Aksara. Jakarta.

Hernanto. F. 1996. Ilmu Usahatani. PT. Penebar Swadaya. Jakarta.

Intriligator, M.D. 1978. Econometric Model. Techniques. and Applications. Prentice Hall Inc. New Jersey.

Koutsoyiannis. 1977. Theory of Econometrics: An Introductory Exposition of Econometric Methods. Second Edition. Macmillan Publishers Ltd. London.

Mudrajad Kuncoro. 2001. Metode Penelitian Kuantitatif. UPP AMP YKPM. Yogyakarta.

Santoso, S. 2000. Buku Latihan SPSS Statistik Parametrik. Elex Media Komputindo. Jakarta.

Setiawan, D. H dan A. Andoko. 2005. Petunjuk Lengkap Budi Daya Karet. Agromedia Pustaka. Jakarta.

Soekartawi.1990. Teori Ekonomi Produksi dengan Produk Bahasan Analisis Fungsi Coob-Douglas. Rajagrafindo Persada Jakarta.

PT.

Sudjana. 1992. Metode Statistika. Tarsito. Bandung.

Supranto, J. 2004. Ekonometri. Ghalia Indonesia. Jakarta.

Tim Penulis PS. 2008. Panduan Lengkap Karet. Penebar Swadaya. Jakarta.

Utomo, T.P., U., Hasanudin., dan E. Suroso . 2012. Agroindustri Karet Indonesia. PT. Sarana Tutorial Nurani Sejahtera. Bandung.

Woelan, Sekar. 2005. Pengenalan Klon Karet Unggul Baru Penghasil Lateks- Kayu. Balai penelitian Sungei Putih. Medan.

Wibowo dan Larasati S. 2012. Analisis Efisiensi Alokatif faktor-faktor Produksi Dan Pendapatan Usahatani Padi ( Oriza Sativa L.) Naskah Publikasi Jurnal.

Winarno, S. 2004. Pengantar Penelitan Ilmiah (dalam Metode Teknik). Kanisius. Bandung 